\title{
Competitive Intelligence and Performance of Selected Aluminium Manufacturing Firms in Anambra State, Nigeria
}

\author{
Hope N. Nzewi ${ }^{1}$, Obianuju M. Chiekezie ${ }^{1}$ \& Adaeze S. Anizoba ${ }^{1}$ \\ ${ }^{1}$ Department of Business Administration, Nnamdi Azikiwe University, Awka, Nigeria \\ Correspondence: Hope N. Nzewi, Department of Business Administration, Nnamdi Azikiwe University, Awka, \\ Nigeria.
}

Received: March 16, 2016

Accepted: April 11, 2016

Online Published: April 22, 2016

doi:10.5430/ijba.v7n3p62

URL: http://dx.doi.org/10.5430/ijba.v7n3p62

\begin{abstract}
The seemingly decreased competitive intelligence awareness among Aluminium firms in Anambra State appear to have caused some companies' management uninformed of a real-time view of what their competitors are doing, product' pricing and slow response to customers' demand for quality products and services offered in the market. Consequently, this study determined the relationship between competitive intelligence and performance of selected manufacturing firms in Anambra State. Specifically, it ascertained the type of relationship between competitor pricing and customer retention. Correlation survey design was used in the study. Data were analyzed using Pearson Product Moment Correlation Coefficient which established the type of relationship between the dependent and independent variables. The findings of the study revealed that competitor pricing has significant positive relationship with customer retention. It is therefore recommended that firms should strive for competitive advantage over their rivals by applying an appropriate pricing strategy which enhances fair pricing dimensions of their products.
\end{abstract}

Keywords: competitive intelligence, performance, competitor pricing, customer retention, aluminium manufacturing firms

\section{Introduction}

Many important changes have occurred in the business environment in the last half century such as constant changes in customer preferences, establishment of new technologies, the intense global competition and increased focus on customer satisfaction (Shih, Liu, \& Hsu, 2010). These changes have placed manufacturing companies today under diverse types of pressure requiring them to increasingly improve their competitive priorities including cost reduction, quality service delivery and rapid response to customers' demand, flexibility, productivity and innovation to produce new products (Alsoboa \& Alduhiate, 2013). In recent years, competitive intelligence has become one of the important concepts of management. Today, companies which have a deeper understanding about their fields of activity and make competitive advantages for themselves are successful in competitive environment (Alizadeh, 2010).

Manufacturing firms use competitive intelligence to compare themselves to other manufacturing firms (competitive benchmarking), to identify risks and opportunities in their businesses which enable them to make decisions. Recently, some industries such as the banking and telecommunication industries realize the importance of identifying what their competitors are doing, how the industry is changing and the information gathered allow these firms to understand their strengths and weaknesses (Adeleke, \& Aminu, 2012),

Due to possible factors like technology and globalization, the business environment has become turbulent. To survive in such a turbulent environment, firms strive for a competitive advantage over their rivals. Competitive intelligence means determining what your business rivals will do before they do it, strategically gaining foreknowledge of your competitor's plans and planning business strategy to countervail their plans (Ezigbo \& Uduji, 2013).

Competitive intelligence improves tactical and strategic decision- making through understanding the competitive environment. It is necessary to understand the competitor: how he thinks, what his strengths and weaknesses are, where he is vulnerable, and where he can be attacked. According to Shih, et.al (2010), in order to sustain a 
competitive position, businesses should prepare to respond promptly to changes in customer preferences, competitors' strategies and technological advancements.

By knowing your competitor, you may be able to predict their next moves, exploit their weaknesses, and undermine their strengths. Competitive intelligence is necessary because managers need to increase the quality of products and services, strategic planning, and market knowledge (Ezigbo \& Uduji, 2013). Competitive intelligence is still a growing phase in Chattered Aluminium Nigeria Limited and Map Aluminium Nigeria Limited in Anambra state due to probable lack of awareness of its benefits and inadequate formal training programmes. It was observed that research and development department in the focused firms centred their attention more internally, that is, what they can do to improve their products, ultimately attracting new customers without paying attention to what other firms are doing. This is probably why they are sidelined by their customers thereby making other firms to have an edge over them.

\subsection{Statement of the Problem}

Businesses deal with customers, suppliers, employees and firms offering similar products and services in order to succeed. These firms are competitors and their objective is the same. Effectively, firms are at war fighting to gain the same resource and territory (the customer).

In today's fast-moving markets, competitive advantage is momentary and there is a call for raising competitive intelligence awareness. But there appears to be no evidence of competitive intelligence awareness and practice in Chattered Aluminium Nigeria Limited and Map Aluminium Nigeria Limited in Anambra state. These firms may not understand what their competitors are doing at the present. Competitors are constantly releasing new and better products and services, adopting aggressive pricing strategies, and finding new ways to enter their competitors' channels. Apparently, businesses fail to have a real-time view of what their competitors are doing, how they are pricing their products, and how their customers are reacting. Not taking into cognizance, that the reputation of their own products and services is determined by what their customers say whether for good or for bad. Chattered Aluminium Nigeria Limited and Map Aluminium Nigeria Limited in Anambra State appear ignorant that they can be the pace setters by increasing their market share through gathering competitive pricing data and adjusting their prices dynamically.

The focused firms may not have the awareness that they can optimize their product strategy by assessing customers' reaction to new product features and product pricing. The possible consequence of not implementing competitive intelligence is that, these manufacturing firms may run the risk of operating in a reactive mode, jeopardizing competitive pricing and customer retention.

\subsection{Objective of the Study}

The major objective of this study is to determine the relationship between competitive intelligence and performance of selected manufacturing firms in Anambra State. The specific objective is to ascertain the type of relationship between competitor pricing and customer retention.

\subsection{Research Question}

What is the type of relationship that exists between competitor pricing and customer retention?

\subsection{Research Hypothesis}

There is no significant positive relationship between competitor pricing and customer retention

\section{Review of Related Literature}

\subsection{Conceptual Review}

\subsection{Competitive Intelligence}

Competitive intelligence is the knowledge and information about the environment in which the organization is working and it enables the organization to gain a competitive advantage and compete against its competitors effectively. It focuses on monitoring a firm's competition to provide the firm with information about what its competition is doing to give it a competitive advantage in business. It helps the company having a competitive position. It also helps strategists to understand the forces that influence the business environment and, more importantly, to develop appropriate plans to compete successfully (Ghannay \& Mamlouk, 2013).

Competitive Intelligence can be defined as actionable recommendations arising from a systematic process that involves planning, gathering, analyzing and disseminating information on the external environment for opportunities 
or developments that have the potential to affect a company's or countries competitive situation (Calof \& Skinner, 1998).

According to Poppa (2009), Competitive Intelligence is continuous process of gathering data, information and knowledge about actors (competitors, customers, suppliers, government) which interact with organization in the business environment in order to support decision making process for enhancing competitiveness of organization. Hughes (2005) avers that competitive intelligence is the tool that provides organizations with a competitive edge through which they can compete with the competition and survive in the market and be profitable at the same time.

The Society of Competitive Intelligence Professionals (SCIP) organization, cited in Nikolaos and Evangelia (2012), defines competitive intelligence as "a necessary, ethical business discipline for decision making based on understanding the competitive environment".

On the other hand, Competitive intelligence is a process for gathering usable knowledge about the external business environment. Competitive intelligence focuses on turning external information into the intelligence required for tactical or strategic decisions relating to the business environment. Furthermore, competitive intelligence is all about 'managing the entire competitive battlefield' (Fleisher \& Bensoussan, 2003). Any organization needs to know its own organization, the competition, and the battlefield, and then be able to analyze and use this information in the decision-making process. The practice of competitive intelligence has become more critical as competitive intensity in the environment has increased because of technological developments, globalization, product availability and variety, distribution improvements, the Internet, and consumer sophistication.

\subsection{Firm Performance}

Firm performance has been identified as the central determinant of firms' competency in retaining customers (Yee, Yeung, \& Edwin, 2010). Firm's performance measurement can be divided into two components namely financial performance (Kaplan \& Norton, 2001) and non-financial performance, which respectively evaluates firms' monetary and non-monetary dimensions (Avci, Madanoglu, \& Okumus, 2011). Financial performance reflects the firm's financial situation which can be evaluated using indicators such as profit margin, return on assets (ROA), returns on sales (ROS), return on investment (ROI) and others (Yee at al. 2010). Firm performance comprises the actual output or results of a firm as measured against its intended outputs .

Non-financial performance measures inherently focuses on the long-term achievement of firms by concentrating on customer gratification, internal business process, productivity, invention, and employee fulfilment (Avci et al. 2011). Furthermore, dimensions such as quality of service, resource consumption, and invention are also influencing firm's non-financial performance (Zigan \& Zeglat, 2010).

According to Zigan and Zeglat (2010), customer satisfaction and loyalty were also found to be the core components of firms' non-financial performance.

\subsection{Competitor Pricing}

Competitor pricing means setting the price of a product or service based on what competitors are charging. Competitive pricing is used more often by businesses selling similar products, since services can vary from business to business while the attributes of a product remain similar. This type of pricing strategy is generally used once a price for a product or service has reached a level of stability, which often occurs when a product has been in the market for a long time and there are many substitutes for the product.

\section{Competitors' Pricing Strategies}

The most common pricing strategies which will prompt competitors to select some specific pricing policies to further focus their pricing planning include:

\section{Lower Pricing Position Strategies}

* Penetration pricing: Pricing products at a loss to gain market share. Offering lower prices to get larger volume of sales. This strategy is use to enter a new market or to position a commodity product.

* Predatory pricing: Deliberate cutting of price to prevent others from entering the market and forcing competitors to compete on price and low profit margins. Offering free gifts and packaging of products/services that competitors cannot meet effectively.

\section{Higher Pricing Position Strategies}

* Image, value, or quality pricing: Pricing to match customers' enhanced perception. Customers see brands as status symbols, in high demand with limited quantities. 
* Market or price skimming: Setting premium pricing on a product that is of high demand in the early stage of its lifecycle. Gaining maximum profit from the market for high- tech or new inventions.

\section{Parity Pricing Position Strategies}

* Going rate pricing: Creating pricing wars between competitors who offer the same or similar products/services. No one charges more to prevent loss of market share. Few competitors control pricing.

* Keystone or target pricing: Setting prices to reach or maintain specific profit levels.

Source: Ewing Marion Kauffman Foundation (2006). Competitive Pricing Definition Investopedia available online at http://www.investopedia.com/terms/c/competitivepricing.asp\#ixzz3jow3zLR (accessed on $19^{\text {th }}$ August, 2015)

\subsection{Customer Retention}

Customer retention is essentially defined as customer's commitment towards firm and its offerings for a specific period of time through their repeat purchases and tendency in spreading positive word of mouth among their social circle (Jeng \& Bailey, 2012).

Repeat purchase intention is regarded as the customer's decision about re-purchasing a chosen product from the same manufacturer, taking into consideration the customer's present condition and other possible occurrences (Yap $\&$ Kew, 2007). Satisfied customers with positive experience will repurchase which will in turn improve firm's performance. It implies that customers' repeat purchase intention are directly influenced by quality of goods provided to customers, low pricing of goods, which will subsequently create favourable experiences for them (Polo, Sese, \& Verhoef, 2011).

Word-of-mouth (WOM) is described as an endorsement and references from satisfied customers about a firm and its offerings, which are considered as an effective tool in business (Mulindwa, 2005). WOM usually includes remarkable comments about a product's performance, service quality and firm's trustworthiness from one customer to another customer. It is believed that exceeding customer's expectation would influence the customers to engage in spreading news about the firm. It will be a competitive advantage for a firm as the spread of positive news is exclusive for a specific firm and does not belong to others. Such advantage enables the customers to easily distinguish their preferred firm from other firms in the market. Besides, such news would increase potential customers' confidence level towards the firm (Mulindwa, 2005).

\section{Theoretical Framework}

This study is anchored on open systems theory which was initially developed by Karl Ludwig von Bertanlanffy (1956), a biologist, but it was immediately applicable across all disciplines. It defines the concept of a system, where "all systems are characterized by a combination of parts whose relations make them interdependent". It refers simply to the concept that organizations are strongly influenced by their environment.

Recently, organizations exist in competitive global environments where there is strong competition for resources, markets, skilled employees and innovations. At the same time, many organizations confront environments that are unpredictable and complex. Organizational environments are multifaceted and can be categorized in the following way: the competition, customers, the technological sector, the regulatory sector, the economic sector, and the socio-cultural sector.

The relevance of this theory to the study is that organizations are highly engaged with their environments. Organizations import capability from the environment. This capability can be achieved by obtaining the information needed to transform that capability into desired outputs through competitive intelligence. The implication here is that this will enable manufacturing firms in Anambra state to develop characteristics and perform processes that will allow them to adapt to constraints, threats, and opportunities.

\subsection{Empirical Review}

Prior studies on competitive intelligence among scholars presented varied perspectives and findings:

Eric and René (2014) conducted a research in South Africa. Their study focused on competitive intelligence implementation challenges of small and medium-sized enterprises. Their research followed a quantitative approach. Questionnaire was used to collect data. Mean and standard deviation were used to analyze the data. The study revealed that SMEs experience the same challenges experienced by large enterprises in implementing competitive intelligence.

Ezigbo and Uduji (2013) carried out a research in three manufacturing firms in Nigeria on why competitive intelligence is necessary in the manufacturing sector. The study was carried out primarily through the survey method 
and interview of employees. Secondary data were obtained through books, journals and internet. Chi-Square and correlation coefficient statistical tools were adopted in analyzing the data using SPSS version 15.00. Findings indicate that Competitive intelligence is necessary because of manager's need to increase the quality of products and services, strategic planning, and market knowledge.

The research of Egberi and Okpako-uyeh (2011) examined competitive intelligence and marketing effectiveness of corporate business organizations in Nigeria. Descriptive survey method was used in collection of data. The research hypotheses were tested using the descriptive statistical methods such as simple percentage, the Pearson product moment correlation coefficient and t-test. Their findings revealed that there was a significant positive relationship between competitive intelligence and organizational profitability.

Rizwan, Imamuddin, Khawaja, \& Rana, (2014) carried out a study in Pakistan on the importance of competitive intelligence in making marketing effective for a business. Questionnaire was used for data collection. T-test was used to analyze the data. Their findings revealed that all the sub variables are significantly used by the organizations in Pakistan to make their marketing effective and thus competitive intelligence is important in making marketing effective for a business.

Nwokah and Ondukwu (2009) carried out an empirical study in corporate organizations in Nigeria. Their work assessed the impact of competitive intelligence on the marketing effectiveness of corporate organizations. Primary and secondary source was used for data collection. Data were analyzed using multiple regression and non-parametric correlation through the use of the Statistical Package for Social Sciences (SPSS) version 12. Their findings revealed that competitive intelligence lead to marketing effectiveness in corporate organizations in Nigeria.

Shakoori, Alvedari, \& Mosaferi, (2014) conducted a research in selected banks in Iran on the role of competitive intelligence in moving customers towards high level loyalty, which lead customers towards being an ambassador of the organization. Questionnaire was used for data collection. Descriptive statistical methods were used. To determine the importance of components of competitive intelligence and loyalty, Friedman ranking test was used. Their findings revealed that among components of high level loyalty, trust, affection, satisfaction, value, brand value and resistance to change have more importance in directing customers towards an ideal loyalty and making ambassadors for bank branches.

Phani, Madhumita, \& Paurav, (2011) conducted a research in India. Their study explored the impact of competitive intelligence practices on the firm's performance in the emerging market context of India. Questionnaire was used for data collection. Their study employed a cross-sectional, survey-based methodology. Their findings revealed that Indian firms that exhibit higher levels of competitive intelligence activities indeed achieve better financial performance results.

Phathutshedzo, and Tiko (2011) carried out a research in South Africa on the impact of competitive intelligence on product and service innovation in organizations. Their research was qualitative in nature. Primary and secondary sources were used for data collections which were interviews and document review. Innovation-Decision Process (Rogers, 1995) was used for data analysis. Their findings revealed that eight factors were found to be critical and influence the deployment of competitive intelligence products and services in the organisation.

\section{Methods}

\subsection{Research Design}

Correlation survey design was employed in this work. The purpose was to collect detailed information from sampled respondents through the use of structured questionnaire.

\subsection{Population of the Study}

Table 1. Sampling frame

\begin{tabular}{llll}
\hline S/N ORGANIZATION & POPULATION SIZE & LOCATION \\
\hline 1. & Armcaster Aluminium & 120 & Onitsha \\
2. & Jimex Aluminium Industries Nig. Ltd & 280 & Nnewi \\
3. Flight Aluminium Nig. Ltd & 180 & Onitsha \\
4. $\quad$ Lento Aluminium Nig. Ltd & 79 & Awka \\
5. & Chattered Aluminium Nig. Ltd & 180 & Nnewi
\end{tabular}




\begin{tabular}{llll} 
6. & Alo Aluminium Nig. Ltd & 167 & Nkpo \\
7. & Map Aluminium \& Steel Ind. Ltd & 171 & Onitsha \\
8. Simco Aluminium Nig. Ltd & 115 & Onitsha \\
9. Best Aluminium Manufacturing Ltd & 106 & Onitsha \\
10. Amunini Aluminium Mfg Co. Ltd & 191 & Onitsha \\
\hline Total & $\mathbf{1 , 5 8 9}$ & \\
\hline
\end{tabular}

Source: Anambra State Ministry of Industry, Trade and Commerce and Field Survey, 2015

From the population of the study listed in Table 1 above, two of the companies were chosen using convenient sampling. The two companies were also picked for representation as they were picked from two out of the three Senatorial districts in Anambra State; the two picked were Chattered Aluminium Nigeria Limited, Nnewi and Map Aluminium Nigeria Limited Onitsha.

Table 2. Population of the focused firms and their proportions

\begin{tabular}{llll}
\hline Organization & Chattered Alluminium & Map Alluminium & Total \\
\hline Number & 180 & 171 & 351 \\
Proportion & 0.51 & 0.49 & 1.0 \\
\hline
\end{tabular}

Source: Field Survey 2015

The distribution of copies of questionnaire followed the proportions calculated above. That is. $51 \%$ of the questionnaire was shared to employees and management of Chattered Aluminium Company while 49\% was distributed to Map Aluminium employees and management.

\subsection{Sample Size and Sampling Technique}

Taro Yamane Formula was used in determining the sample size, the formula is given below as:

$$
n=\frac{\mathrm{N}}{1+N(e)^{2}}
$$

Where $\mathrm{N}=$ population (351)

$$
\begin{aligned}
& n=\text { sample size } \\
& \mathrm{e}=\text { error estimate }(5 \%)
\end{aligned}
$$

Table 3. Proportions

$$
\begin{gathered}
n=\frac{351}{1+351(0.05)^{2}} \\
n=\frac{351}{1.8775} \\
n=187
\end{gathered}
$$

\begin{tabular}{llll}
\hline Proportion & Organization & Sample Size & Total \\
\hline 0.51 & Chattered & 187 & 95 \\
0.49 & Map & 187 & 92 \\
& Total & & $\mathbf{1 8 7}$ \\
\hline
\end{tabular}

Source: Field Survey 2015

From Table 3 above, 95 copies of questionnaire were distributed to the employees and management of Chattered Aluminium while 92 copies were shared to the employees and management of Map Aluminium. 
Table 4. Response rate to the questionnaire

\begin{tabular}{lllll}
\hline S/N & Organization & No Distributed & No returned & \% of Response \\
\hline 1. & Chattered Aluminium & 95 & 92 & $49 \%$ \\
\hline 2. & Map Aluminium & 92 & 90 & $48 \%$ \\
\hline & Total & $\mathbf{1 8 7}$ & $\mathbf{1 8 2}$ & $\mathbf{9 7 \%}$ \\
\hline
\end{tabular}

Source: Field Survey 2015

Table 4 above shows that 187 copies of questionnaire were distributed in appropriate proportions, out of which 182 were filled and collected. Out of the filled and collected questionnaire, two copies were not used because of wrong filling of the questionnaire which invalidated them, thus, the researcher used 180 copies for the study and this represents $96 \%$ of the total sample size.

\subsection{Instrument for Data Collection}

The instrument employed to collect data for this study was a questionnaire. The questionnaire was structured in a Likert scale of 5 ranging from strongly agree to strongly disagree.

\subsection{Validity of the Instrument}

A combination of content and face validity was employed to validate the instrument (questionnaire) used in collecting data. The face validity was based on the face value of the questionnaire while the content validity was meant for coverage. Copies were sent to experts in management for their comments and corrections. Their corrections were made in the final production of the questionnaire.

4.6 Reliability of the Instrument

Source: SPSS ver. 20

\begin{tabular}{ll}
\hline \multicolumn{2}{l}{ Reliability Statistics } \\
\hline Cronbach's Alpha & N of Items \\
\hline 821 & 10 \\
\hline
\end{tabular}

\subsection{Method of Data Analysis}

The data were analyzed using the Pearson Product Moment Correlation Coefficient in order to determine the type of relationship that exists between the dependent and independent variables. The level of significance used was $5 \%$ while $95 \%$ confidence interval reliability was adopted.

\section{Data Presentation and Analysis}

\subsection{Data Analysis}

In line with the hypothesis formulated, data were presented and analyzed using Pearson Product Moment Correlation Coefficient.

\section{Correlations}

\begin{tabular}{|c|c|c|}
\hline & $\begin{array}{l}\text { COMPETITOR } \\
\text { PRICING }\end{array}$ & $\begin{array}{l}\text { CUSTOMER } \\
\text { RETENTION }\end{array}$ \\
\hline $\begin{array}{l}\text { COMPETITOR PRICING Pearson Correlation } \\
\text { Sig. (2-tailed) }\end{array}$ & 18 & $\begin{array}{l}.946^{* *} \\
.000 \\
180\end{array}$ \\
\hline $\begin{array}{c}\text { CUSTOMER RETENTION } \text { Pearson Correlation } \\
\text { Sig. (2-tailed) }\end{array}$ & $\begin{array}{l}.946^{* *} \\
.000 \\
180\end{array}$ & $\begin{array}{r}1 \\
180\end{array}$ \\
\hline
\end{tabular}

**. Correlation is significant at the 0.01 level (2-tailed).

Source: SPSS Ver. 20 


\section{Findings}

The results obtained from the correlation analysis show that there is a positive relationship between the two variables with a coefficient of .946 , and the $\mathrm{p}$ value which is .0000 at less than 0.01 (2-tailed test). Therefore, the null hypothesis is rejected while the alternate hypothesis is accepted. This shows a strong positive relationship between Competitor Pricing and Customer Retention.

\section{Discussion of Finding/Management Implications}

The findings from data analyses and hypothesis testing showed a very strong positive relationship between dependent (customer retention) and independent variable (competitor pricing). The management implication is that an effective and efficient pricing strategy has greater chances of achieving customer retention despite intensive competition among firms in the Aluminium industry. This shows that competitor pricing has great influence on customer retention. The result supports the view of Adeleke and Aminu (2012), Ezigbo and Uduji(2013), who aver that high service quality is not a guarantee for customer attraction and retention. They posit that price is quite a crucial factor to induce customer switching either temporarily or permanently, and in Nigeria price has been used to attract and retain new customers.

This finding also corroborates the result of Wiley (2005), Egberi and Okpako-uyeh(2011), who stated that the whole idea of adequate pricing of company products and services is mainly targeted to positively influence a firm's sales volume which indicates why firms at entry stage use penetrative pricing where they put their products in the market at a slightly lower price than that of competitors. The way management of firms decide to price their products have a high effect on the rate of customer retention.

\section{Conclusion}

Following from the findings, it is concluded that competitor pricing has high level of influence on customer retention. The more effective and efficient the competitor pricing is, the higher the rate of customer retention. Therefore, the continuous adoption of different pricing strategies by the firms studied establishes the strong positive relationship between competitor pricing and customer retention.

\section{Recommendations}

Emanating from the findings and conclusion, the following recommendations are made:

* Firms should strive for a competitive advantage over their rivals by applying an appropriate pricing strategy which will help in ensuring price fairness on the pricing dimensions of their products.

* Aggressive promotional campaigns, particularly sales promotional activities should be conducted from time to time to keep loyal customers and attract new potential customers.

* Effective post-purchase activities should be in place to help handle customer complaints or grievances quickly so as not to suffer defect from already existing customers.

\section{References}

Adeleke, A., \& Aminu, S.A. (2012), The Determinants of Customer Loyalty in Nigeria's GSM Market. International Journal of Business and Social Science, 3(14), 209-222.

Alizadeh, S. (2010). Role of intelligence in improving organizational performance. Quarterly Journal of Communication and Education in Human Resources Development, 1, 91-101.

Alsoboa, S. S., \& Aldehayyat, J. S. (2013). The impact of competitive business strategies on managerial accounting techniques: A study of Jordanian public industrial companies. International Journal of Management, 30(2), 545-555.

Anica, I. P., \& Cucui, G. (2009). A Framework for Enhancing Competitive Intelligence Capabilities using Decision Support System based on Web Mining Techniques. Int. J. of Computers, Communications \& Control, IV(4), 326-334

Avci, U., Madanoglu, M., \& Okumus, F. (2011). Strategic orientation and performance of tourism firms: Evidence from a developing country. Tourism Management, 32(1), 147-157.

Calof, J.L., \& Skinner, B. (1998). Competitive Intelligence for government officers: a brave new world. Optimum, $28(2), 38-42$.

Charity, A., Ezigbo, \& Joseph, I. (2013) Uduji. Managing Competitive Intelligence for Strategic Advantage. European Journal of Business and Management, 5(3). 
Egberi, A. K., \& Okpako-Uyeh, I. O. B. (2011). Competitive intelligence and marketing effectiveness of corporate business organizations in Nigeria. International Journal of Economic Development Research and Investment, 2(3).

Ewing Marion Kauffman Foundation. (2006). Competitive Pricing Definition Investopedia. Retrieved 19th August, 2015, from http://www.investopedia.com/terms/c/competitivepricing.asp\#ixzz3jow3zLcR

Fleisher, Craig, S., \& Babette, B. (2003). Strategic and Competitive Analysis: Methods and Techniques for Analyzing Business Competition. Upper Saddle River, NJ: Prentice Hall.

Gladson, N., \& Ondukwu, A. (2009). Competitive intelligence and marketing effectiveness in corporate organizations in Nigeria. African Journal of Marketing Management, 1(1), 010-022.

Gross, M. (2000). Competitive intelligence: A librarian's empirical approach. Searcher, 8(8), 1-5.

Hughes, S. (2005). Competitive Intelligence as Competitive Advantage. Journal of Competitive Intelligence and Management, 3, 3-14.

Jeng, D. J. F., \& Bailey, T. (2012). Assessing customer retention strategies in mobile telecommunications: Hybrid MCDM approach. Management Decision, 50(9), 1570-1595.

Kaplan, R. S., \& Norton, D. P. (2001). Transforming the Balanced Scorecard from Performance Measurement to Strategic Management. Part-1. Accounting Horizon, 15(1), 87-104.

Louise, J. (2012). What is Organisational Performance? Pitcher Partners Growth. Retrieved 11th August, 2015, from http://www.growth.pitcher.com.au/resources/articles/what-is-organisational-performance

Mulindwa, C. (2005). Relationship Marketing and Customer Retention in the Printing Equipment Industry: A Case Study of Heidelberg East Africa Ltd. Master's Dissertation, Makerere University.

Nikolaos, T., \& Evangelia, F. (2012). Competitive Intelligence: concept, context and a case of its application. Science Journal of Business Management, 2012(2), 15. Retrieved 25th July, 2015, from http://www.sjpub.org/sjbm.htm

Phani, T., Madhumita, B., \& Paurav, S. (2011). Competitive intelligence and firm's performance in emerging markets: an exploratory study in India. Journal of Business \& Industrial Marketing, 27(3), Emerald Group Publishing Limited, 242-254. http://dx.doi.org/10.1108/08858621211207252

Phathutshedzo, N., \& Tiko, I. (2011). The impact of competitive intelligence on products and services innovation in organizations. International Journal of Advanced Computer Science and Applications, 2(11).

Polo, Y., Sese, F. J., \& Verhoef, P. C. (2011). The Effect of Pricing and Advertising on Customer Retention in a Liberalizing Market. Journal of Interactive Marketing, 25(4), 201-214.

Rizwan, R, Imamuddin, K., Khawaja, A., \& Rana, I. (2014). Competitive Intelligence and Marketing Effectiveness of Organizations: An Investigation from Pakistan. European Scientific Journal, 10(13).

Rogers E. M. (1995). Diffusion of Innovations (4th ed.). New York: Free Press.

Shakoori, Y., Alvedari, H., \& Mosaferi, Y. (2014). Investigation of the Role of Competitive Intelligence in Directing Customers toward Loyalty, Support and Being Organizational Ambassador. Indian Journal of Fundamental and Applied Life Sciences, 4(S4), 3149-3155. Retrieved 16th August, 2015, from www.cibtech.org/sp.ed/jls/2014/04/j1s.htm

Shih, M., Liu, D., \& Hsu, M. (2010). Discovering competitive intelligence by mining changes in patent trends. Expert Systems with Application, 37(4), 2882-2890.

Society of Competitive Intelligence Professionals. (2008, April). Retrieved 19th August, 2015, from http://www.scip.org/ci/faq.asp

Tshilidzi, E. N., \& René, P. (2014). Competitive intelligence Implementation challenges of small and medium-sized enterprises. Mediterranean Journal of Social Sciences, 5(16).

Wiley, S. (2005). Strategic pricing and performance. Strategic Management Journal, (17), 77-91.

Yap, S. F., \& Kew, M. L. (2007). Service quality and customer satisfaction: antecedents of customer's re-patronage intentions. Sunway Academic Journal, (4), 59-73.

Yee, R. W., Yeung, A. C., \& Edwin Cheng, T. C. (2010). An empirical study of employee loyalty, service quality and firm performance in the service industry. International Journal of Production Economics, 124(1), 109-120.

Zigan, K., \& Zeglat, D. (2010). Intangible resources in performance measurement systems of the hotel industry. Facilities, 28(13/14), 597-610. 